\title{
ANTONINA DOMAŃSKA - SZKIC DO PORTRETU
}

Zofia Szczupaczyńska - bohaterka kryminałów retro Maryli Szymiczkowej$^{1}$, to postać wyjątkowa. Nobliwa małżonka krakowskiego profesora medycyny jest wzorową panią domu, pamięta o kupieniu pulardy na obiad i wina przeciwko cholerze. Jak przystało na prawdziwą obywatelkę Stołecznego Królewskiego Miasta Krakowa obowiązki domowe łączy z baczną obserwacją krakowskiej codzienności. Nudząc się jednak potwornie w swej mieszczańskiej doskonałości, zostaje detektywem.

Wbrew pozorom fikcyjna postać detektywa w spódnicy ma sporo wspólnego z bohaterką tego szkicu. Wśród cracovianistycznych źródeł, wykorzystanych przez autorów tego uroczego kryminału znalazła się książka Krystyny Jabłońskiej Ostygłe emocje, która opowiada o Krakowie przełomu wieków, sięgając między innymi do fragmentów prywatnych zapisków autorki Paziów króla Zygmunta. Na trop Antoniny Domańskiej jako jednego z ważniejszych pierwowzorów Zofii Szczupaczyńskiej naprowadzają całkiem wyraźne ślady. Przede wszystkim figura męża - profesora medycyny i jego nieco szalonego asystenta (pioniera seksuologii, doktora Stanisława Kurkiewicza), zaprawione lekką ironią opisy codzienności mieszczańskiego domu, a przede wszystkim żywa inteligencja bohaterki, jej niepodrabialny styl oraz ocierająca się o impertynencję błyskotliwość.

Postać sympatycznej Zofii Szczupaczyńskiej jest rewersem najsłynniejszego literackiego portretu Domańskiej utrwalonego na kartach arcydzieła Stanisława Wyspiańskiego. Inspirowana Domańską figura Radczyni, zaklęta niczym w bursztynie w Boyowej plotce o Weselu, na zawsze już pozostanie obdarzoną „dystynkcją starszą matroną” ${ }^{2}$, siostrą pań Dulskiej i Cho-

1 Zob. M. Szymiczkowa [J. Dehnel, P. Tarczyński], Tajemnica domu Helclów, Kraków 2015; M. Szymiczkowa [J. Dehnel, P. Tarczyński], Rozdarta zasłona, Kraków 2016; M. Szymiczkowa [J. Dehnel, P. Tarczyński], Seans w Domu Egipskim, Kraków 2018.

2 „Dystynkcja starszej matrony” to określenie, jakim posługiwano się, opisując 
mińskiej z dramatów Gabrieli Zapolskiej i Jana Augusta Kisielewskiego. Pozostanie krakowską damą, której wystudiowane pozy i bon moty („Wyście sobie, a my sobie. / Każden sobie rzepkę skrobie”, „Topi się, kto bierze żonę” i słowa zwrócone do świeżo poślubionej żony Lucjana Rydla: „No, moja ty urocza panno młoda, / Jakże wy sobie będziecie żyli? [...] o czym wy będziecie mówili, [...] On wykształcony, ty bez szkół”) zamykają ją w świecie drobnomieszczańskich przesądów i rytuałów, czyniąc figurą niepokojąco śmieszną, ale też i nieco kołtuńską.

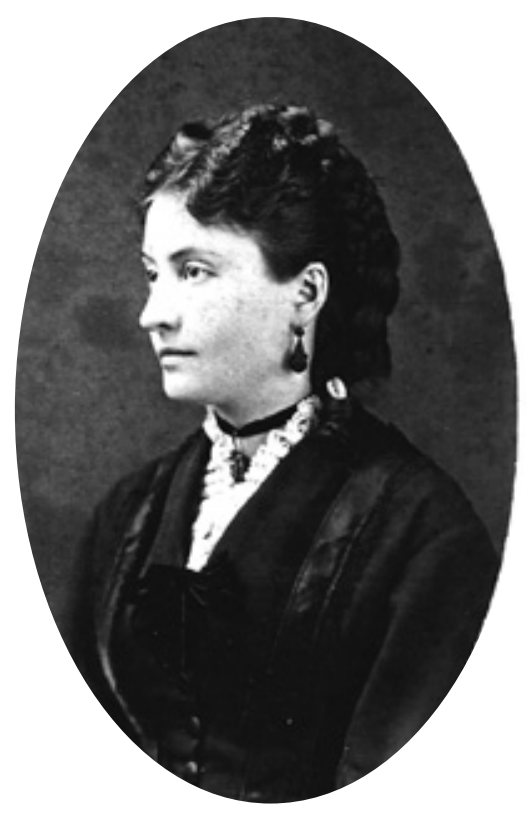

Antonina Domańska

Paradoksalnie, choć tak odmienne, obie te literackie kreacje są w równym stopniu odległe od inspirującej je „prawdziwej” Antoniny Domańskiej. Ona sama pozostaje skryta w gęstym cieniu historii, która przechowując pamięć o tak zwanych wielkich bohaterach, okrywa zapomnieniem zwykłych ludzi i ich świat. Jeśli chcieć odzyskać pamięć o Domańskiej, wydobyć jej historię spod warstw naniesionych przez środowiskowe plotki i ich literackie reminiscencje, należy sięgać nawet nie tyle do trącących już dziś myszką utworów pisarki, ile do jej prywatnych zapisków i zachowanej korespondencji. Jednak tu, już na samym początku pojawia się trudność nie do pokonania. Te zapiski, choć powszechnie znane i często cytowane, nie są dostępne. Pamiętnikarskie notatki Domańskiej znamy bowiem jedynie

postać Radczyni i jej kostiumy. Zob. R. Węgrzyniak, Radczyni, w: tegoż, Encyklopedia „Wesela” Stanistawa Wyspiańskiego, Kraków 2001, s. 108-109. 
we fragmentach i w dodatku - z drugiej ręki. W latach 1979-1980 pojedyncze ich wyimki ukazywały się na łamach „Echa Krakowa” w interesująco redagowanej rubryce $W$ Krakowie przed 80. laty. Następnie w 1987 roku, już w szerszym wyborze pojawiły się na kartach wspomnianej książki Jabłońskiej Ostygte emocje.

Określam je jako niedostępne, bo muszę wierzyć na słowo, że istnieją. Mimo konsultacji z wieloma cenionymi cracovianistami nie potrafiłam ustalić, gdzie dziś szukać rękopisów Domańskiej, nie wiem, kto prowadził rubrykę w „Echu Krakowa” i skąd czerpał materiały. Niestety nie potrafię wskazać także, z jakich zbiorów prywatnych korzystała Jabłońska i na ile wiernie oddała kształt tych zapisków ${ }^{3}$. Przeprowadzona przeze mnie kwerenda ujawnia paradoksalną sytuację: nie sposób nie korzystać z materiałów Domańskiej, bo są pełnym kolorów i emocji opisem tamtego Krakowa, równocześnie nie sposób z nich korzystać, bo nie można zweryfikować ich prawdziwości. Świetna dziennikarska robota Jabłońskiej nie jest też w stanie sprostać wyśrubowanym standardom tekstu naukowego ${ }^{4}$.

Mój honor dziewiętnastowiecznika został przynajmniej po części uratowany dzięki życzliwości państwa Rydlów, którzy udostępnili mi znajdujące się w ich posiadaniu listy Antoniny Domańskiej ${ }^{5}$. Choć pewności nadal nie mam, to podobieństwo stylu, pewne powtarzające się frazy pozwalają przypuszczać, że cytowane przez Jabłońską zapiski nie są falsyfikatem, że tak mogła pisać Antonina Domańska - dama, którą Zofia Ciechanowska tak charakteryzowała: „[...] cechowały ją żywe, wesołe usposobienie, uroda, bystra inteligencja, dosadność i prawda w sposobie wyrażania się" ${ }^{\text {. }}$

3 Autorka w bibliografii podała jedynie: „A. Domańska, Zapiski kronikarskie z lat 1898-1901 - rękopisy ze zbiorów prywatnych”. Zob. K. Jabłońska, Ostygłe emocje, Kraków 1987, s. 213. Brak informacji, czy tak częste w cytatach fragmenty zapisywane rozstrzelonym drukiem to edytorska ingerencja Jabłońskiej, czy element oryginalny oddający specyfikę emocjonalnego stylu Domańskiej.

$4 \quad \mathrm{Na}$ informacje podane przez Jabłońską powołuje się także Węgrzyniak (dz. cyt.). Zob. też: K. Grodziska, Krakowianki zapomniane. O niezwykłych paniach pochowanych na Cmentarzu Rakowickim 1803-1920, Kraków 2011.

5 W tym miejscu chciałabym podziękować pani prof. Isabel Röskau-Rydel i prof. Janowi Rydlowi za udostępnienie znajdującej się w ich posiadaniu korespondencji Antoniny i Stanisława Domańskich z Lucjanem Rydlem. Dziękuję też panu Piotrowi Szmigielskiemu, który sprawuje pieczę nad archiwami rodziny Rydlów. Wszystkie cytowane przeze mnie fragmenty korespondencji Antoniny Domańskiej pochodzą z tych zbiorów.

6 Źródłem podstawowym dla biografii Domańskiej wciąż pozostaje hasło w PSB. Zob. Z. Ciechanowska, Domańska z Kremerów Antonina, w: Polski słownik biograficzny, Kraków 1939-1946, t. 5, s. 299. Autorka powołuje się na informacje 
Zdaję sobie sprawę z podjętego ryzyka, bo jak inaczej nazwać kreślenie portretu pisarki na podstawie niepewnych materiałów, jednak zarówno ze względu na literacką atrakcyjność tych zapisków, jak i ich wartość dokumentacyjną chciałabym to wyzwanie podjąć ${ }^{7}$. Mam nadzieję, że ten desperacki gest badacza, któremu wymykają się cenne materiały, może choć w niewielkim stopniu przyczyni się, jeśli nie do odnalezienia zapodzianych papierów Domańskiej, to przynajmniej do uzmysłowienia, jak szybko przebiega proces dezintegracji materialnego dziedzictwa przeszłości - nie tyle wspaniałych dzieł sztuki, ile świadectw minionej codzienności, świadectw dokumentujących los zwykłych niezwykłych ludzi. Jeszcze w 1987 roku, gdy ukazała się książka Krystyny Jabłońskiej, rękopisy Antoniny Domańskiej wydawały się znajdować w zasięgu ręki...

Jest pewnym truizmem twierdzenie, że literaturze polskiej doskwiera brak wiarygodnego portretu klasy średniej ${ }^{8}$. Nie mamy powieści na miarę Buddenbrooków Thomasa Manna. W zdominowanej przez tradycję szlachecką kulturze polskiej mieszczanie pojawiają się z rzadka i to albo w ckliwym biedermeierowskim ujęciu, albo w stereotypowo czarnym, kołtuńsko-Dulskim wydaniu.

Na tym tle pamiętnikarskie zapiski Antoniny Domańskiej, nawet w dokonanym przez Krystynę Jabłońską wyborze, okazują się prawdziwą rewe-

zebrane od córki pisarki - Marii Domańskiej i znajomej rodziny - Jadwigi Zieleniewskiej. Opinię na temat Domańskiej potwierdza także syn wieloletniego wydawcy pism Domańskiej, Stanisław Arct: „Lubiłem bardzo panią Antoninę Domańską, autorkę z humorem napisanych opowiadań Moje dzieci, W Woli Tenczyńskiej i powieści Paziowie króla Zygmunta. Domańska, dość tęga blondynka, gładko zaczesana, miała zawsze jakieś przyjemne słówko dla mnie i była taka bardzo swojska” (S. Arct, Okruchy wspomnień, Warszawa 1962, s. 167).

7 Ograniczenia wynikające ze statusu i niekompletności podstawy materiałowej znacząco wpłynęły na kompozycję prezentowanego tekstu. Podejmuję w nim jedynie te kwestie, w których wykorzystane materiały stanowią rodzaj ilustracji dopełniających portret bohaterki szkicu, nie są zaś argumentem przesądzającym o zasadności stawianych tez. Wątpliwości względem wykorzystanych materiałów przesądziły również o konieczności rezygnacji z tak ważnego wątku rozważań, jakim powinna stać się refleksja nad reprezentowanym przez Domańską typem „mieszczańskości”. Temat ten mógłby stać się ciekawym (może nawet gorzkim) kontrapunktem dla prezentowanej, nieco może zbyt nostalgicznej, opowieści o zapomnianej autorce Paziów króla Zygmunta.

8 Za: T. Walas, Straszni mieszczanie i ich dusza, w: G. Zapolska, Moralność pani Dulskiej. Ich czworo. Lekcja literatury z Teresą Walas, Kraków 1997, s. 5. 
lacją. Przynoszą opowieść o miejskiej codzienności, o świecie ludzi skrzętnych, zapobiegliwych, znających wartość pieniądza, a równocześnie dbających o standard życia i podkreślających znaczenie swej inteligenckiej nobilitacji. Opowieść o świecie, gdzie tradycjonalizm nie przybiera form dworkowych, a przejawia się w kultywowaniu mieszczańskich cnót i dbałości o wspólnotę (rodzinę, kręgi towarzyskie i profesjonalne), gdzie polski patriotyzm mocno łączy się z lokalnością miejską i regionalną. Opowieść o świecie zdeklarowanych konserwatystów, którzy trochę wbrew głoszonym poglądom uchylali drzwi nowoczesności. Wreszcie, jest to opowieść pisana przez niezwykłą kobietę - żonę, matkę, przy tym zaprzysięgłą tradycjonalistkę, która choć bardzo lubiła pozować na nobliwą matronę, to zostając powieściopisarką, naruszyła powszechnie obowiązujący stereotyp. Kobietę, która na portretowych fotografiach Stanisława Bizańskiego sprawia wrażenie osoby ściśniętej gorsetem konwenansu, ale już na kartach swych zapisków zza surowych min i majestatycznych póz ujawnia osobowość pełną temperamentu i pasji. Last but not least - kobietę, która okazuje się niezwykle spostrzegawczą rejestratorką zdarzeń swej współczesności i interesującą pisarką.

\section{Ciotka}

Obecność Antoniny Domańskiej na kartach literatury polskiej zawsze już będzie wiązać się z postacią Lucjana Rydla. Pisarka była stryjeczną siostrą Heleny Rydlowej z Kremerów, matki autora Betlejem polskiego, on sam zaś nazywał ją po prostu ciotką ${ }^{9}$. Gdyby nie bronowickie wesele Rydla, Domańska nie znalazłaby się na kartach dramatu Wyspiańskiego. Gdyby nie Boyowa plotka o Weselu, nie stałaby się wcieleniem obskurantyzmu i ikoną wszystkich „strasznych” ciotek biadających nad współczesnym upadkiem obyczajów.

Zapiski i listy Domańskiej tylko częściowo potwierdzają ten utrwalony przez Boya, a dziś powszechnie obowiązujący portret. Rzeczywiście, pierwszą reakcją profesorowej na wieść o planowanym małżeństwie ulubionego siostrzeńca miało być oburzenie i poczucie zgrozy wobec nadciągającego skandalu i rodzinnego trzęsienia ziemi:

Omal mnie dzisiaj [Włodzimierz Tetmajer] na tamten świat nie wyprawił! Mało trupem nie padłam. Palpitacje mnie chwyciły i sama już nie wiem, co robić. Co myśleć o tym wszystkim. Ledwie Lucek [Rydel] do Włodzia [do Bronowic] wyjechał, już w najmłodszej Mikołajczykównie rozkochał się na śmierć i życie. Coś tam o ślubie już nawet podobno mówią... A Włodzio spokojnie mi mówi, że się ze mną spowinowaci. W powinowactwo to ja wchodzić mogę, ale tylko z Tetmajerami, o jakichś tam Mikołajczykach nawet słyszeć nie chcę! Jak o tym uprzedzić Rydlową? Co

9 R. Węgrzyniak, Domańska Antonina, w: tegoż, Encyklopedia „Wesela”..., s. 28. 
zrobić z Luckiem? Najszybciej wyciągnąć go od Włodzia, wyprawić w świat, pannami otoczyć - niech wybiera, przebiera, niech flirtuje, zdradza, bałamuci, niech się żeni z kim chce, tylko nie z chłopką!!! ${ }^{10}$

Rychło jednak zwyciężył pragmatyzm i, jakże ludzka, ciekawość:

Świat stanął na głowie i nogami fika, więc się wszystko wywróciło do góry dnem i jedynie Kazia Tetmajera stać na oświadczenie, że jemu całkiem obojętne, z kim żeni się Lucek [Rydel]. Mnie NIE! - [...] mnie serce pęka, jak sobie uprzytomnię, że ta dziewczyna z Bronowic, niby żona Lucka, aleć chłopka przecież - będzie miała prawo, ba! obowiązek mianować mnie cIOTKĄ! Wszystko we mnie zamiera na samą myśl, a tu jeszcze czeka mnie taki ślub i wesele, na które pół Krakowa pobieży, bo Lucek wszystkich sprasza. Myślę sobie: nie pójdę, do łóżka się włożę, zachoruję, umrę, w ciemny grób mnie złożą, ale sromoty uniknę. Ale nawet ten zbytek mi wzbroniony: PAREŃSKA suknie z Paryża sprowadza, bo jakże bez niej coś dziać się by tutaj śmiało! A kim jest Pareńska dla Lucka - tylko znajomą, JA - jego ciotką, więc kto tam być powinien: ona czy ja? BĘDĘ! I utrzymam fason! [...] I jeszcze jedno - nigdy nie byłam na wiejskim weselu, a to poznać trzeba! ${ }^{11}$

Najbardziej zdumiewający okazuje się jednak ciąg dalszy tej niedopowiedzianej już przez Boya historii. „Straszna” ciotka może i nie do końca potrafiła pozbyć się swych uprzedzeń, ale w listach często prosiła Lucka: „Ucałuj bardzo Jadwinię i dzieci ode mnie”, „Weź u Jadwini długi urlop, a ja ją za to pocałuję w nosek". Jadwisia, Jadwinia wzmiankowana jest w listach z serdeczną życzliwością i choć pewnie nigdy nie stała się dla ciotki Domańskiej partnerką salonowych konwersacji, to gdy ta znalazła się w kłopocie, nie wahała się w 1915 roku prosić: „Moja droga Jadwisiu! Czy nie mogłabyś jakoś poradzić na moją biedę? Strasznie mi potrzeba pieniędzy”.

Boy, pisząc o pierwowzorze Radczyni, iż z temperamentu była „kostyczna i weredyczka" 12 , brał pod uwage jedynie oficjalne oblicze profesorowej Domańskiej. Nigdy mu nie przyszło do głowy zapytać, skąd zatem wzięła się autorka, jak sam oceniał, uroczych opowieści dla dzieci. Tymczasem zagadkę łatwo rozwiązać, sięgając do korespondencji Domańskiej. Tam poważna krakowska matrona odsłaniała cały swój wdzięk i dowcip: menty listów i dzienników Domańskiej cytuję za „Echem Krakowa”, gdzie ukazały się wcześniej niż w książce K. Jabłońskiej. Kształt graficzny i interpunkcja w obu źródłach są identyczne, jednak autorka Ostygłych emocji niekiedy włącza fragmenty tekstów Domańskiej w tok swojego wywodu, co utrudniało precyzyjne oddanie cytatu.

12 T. Boy-Żeleński, Plotka o „Weselu”, w: „Wesele” we wspomnieniach i krytyce, oprac. A. Łempicka, Kraków 1970, s. 24. 
Całuję Cię bardzo, syneczku złoty, napisz karteczkę króciutką, bo wiem, że we wakacje przestajesz używać pióra i atramentu, imając się kosy i grabi. Do śmierci i po śmierci wierna, Ciotka.

Albo takie zaproszenie z 1913 roku:

A w Rudawie, nie na ławie,

Ino w łóżeczku, będziesz spał,

Luteczku, na materacu, drogi

pajacu. Agrestu zatrzęsienie

aż cierpnie podniebienie!

$[\ldots]$

Całuję Cię jak syna,

Na cały świat jedyna

Domańska Antonina.

W zapiskach i korespondencji kryje się też jedna z odpowiedzi na pytanie, jak to się stało, że Domańska została autorką powieści historycznych. Odkrywcą jej talentu narracyjnego miał być Lucjan Rydel i to on także miał namawiać ciotkę, by sięgnęła po pióro:

Przychodzi dzisiaj Lucek [Lucjan Rydel] [...] i trajluje: Cioteczka tak porywające listy pisze, że aż szkoda na to talentu i tak dalej i dalej, by w końcu wyjawić, że widzi we mnie iskrę bożą, więc żebym zamiast listów do bliskich - powieści pisała... Chłopaku - ja na to - jak wiesz, te drzwi prowadzą do wyjścia, zanim je za sobą zamkniesz, dowiedz się, że twoja ciotka wszystko ma dobrze poukładane w głowie. Chuchaj w iskrę swojego ukochanego Stasia Wyspiańskiego - niech się roznieci jak najbardziej wspaniałym płomieniem! Wmawiaj, co chcesz i komu chcesz - ale ode mnie wara! Nie będę pisała żadnych powieści. A uparciuch swoje: - Będzie, cioteczka pisała, na pewno! NIE BĘDĘ!!!... ${ }^{13}$

Najwyraźniej rola Rydla nie ograniczyła się tylko do incydentalnej inspiracji, bo do rozbudzania pisarskich pasji ciotki zabrać miał się on nad wyraz metodycznie:

A tak, tak, smarkacz się nade mną wprost znęca! Talent pisarski we mnie na siłę wyrabia. Czytuje mi Kroniki Długosza, podstępnie wciąga w dyskusję ciekawą, co z ręką na sercu stwierdzam. I wymusza ode mnie pisemne raporty. Piszę mu więc dla świętego spokoju, ale i z ciekawości, jak mi też to w piśmie wyjdzie. Lucek twierdzi, że bardzo dobrze. Niech będzie najlepiej, ale nic z tego nie wyjdzie, choć Lucek już trzy książki widzi, książki dla starszych dzieci, historyczne, niby mojego pióra. Ale mnie ani w głowie być panią Jadwigą z Łobzowa! ${ }^{14}$

14 K. Jabłońska, dz. cyt., s. 115. 
Listy profesorowej poświadczają także, że chętnie korzystała z wiedzy historycznej i literackiego doświadczenia Rydla. Domańska konsultowała z tym „utrapieńcem” rozwiązania fabularne zastosowane w Historii żóttej ciżemki i prosiła w 1913 roku o pomoc w uzupełnieniu detalu historycznego przy pisaniu Krysi Bezimiennej:

Widzisz, Luteczku, jaki niedobry z Ciebie chłopczyczek! To strach doprawdy!

Ja do gałgana piszę: powiedz mi krótko a węzłowato, dlaczego Batory wojował z Moskwą, bo go przecie nie poszlę na wyrypy zdobywać Połock, muszę choć w dziesięciu wierszach porezonować o przyczynie tej wojny. A on (to znaczy ów gałgan) pali mi trzy strony różności, a tego, czego jak ona kania [...] wyglądam, ani dudu.

Nawet dziś, po tylu latach, ujmuje ciepło relacji łączącej ciotkę i "przebrzydłego smarkacza”. W przywołanych zapiskach wiele jest śladów familijnych sympatii, ale też i pisarskiego koleżeństwa, jakie ich połączyło.

\section{Radczyni}

Antoninie Domańskiej jako żonie swojego męża tradycyjnie przysługiwały tytuły: najpierw doktorowej, a potem profesorowej. Wyspiański, nazywając inspirowaną nią postać mianem radczyni, w jakiejś mierze uczynił Domańskiej despekt. Profesorowa to zawsze profesorowa, a żona urzędnika miejskiego to tylko żona urzędnika miejskiego. Choć sama zainteresowana mogła mieć (i chyba miała) do artysty pretensje, to dziś warto zauważyć niezwykłą trafność tego określenia. Dzięki tej drobnej złośliwości Wyspiańskiego natrafiamy na niezwykły wprost temat: Antonina Domańska i jej Kraków.

Na pozór temat ten bardziej oczywisty wydaje się w kontekście męża bohaterki tego szkicu - Stanisława Domańskiego, który o sobie mawiał: „Gente Cracoviensis, natione Polonus” i który swą karierę profesorską konsekwentnie łączył z aktywną działalnością we władzach miasta. Od 1881 roku przez trzydzieści pięć lat był członkiem Rady Miasta Krakowa i „przyczynił się przez swą inicjatywę do wprowadzenia urządzeń, które pod względem higienicznym podniosły Kraków w rzędzie miast polskich na miejsce naczelne"15. Mowa tu o zaangażowaniu Domańskiego w prace przy instalacji „gromochronów", przy budowie miejskiego wodociągu, nowoczesnej rzeźni miejskiej, oczyszczaniu dołów kloacznych, modernizacji gazowni i utworzeniu elektrowni miejskiej. Gdy w 1915 roku profesor odchodził na emeryturę, został uhonorowany tytułem "pierwszego obywatela miasta Krakowa”.

Antonina Domańska nie była rodowitą krakowianką. Pisarka urodziła się w Kamieńcu Podolskim, gdzie jej ojciec - Aleksander Kremer prowadził 
praktykę lekarską. Z Krakowem związana jest od 1865 roku, kiedy po klęsce powstania styczniowego rodzice zmuszeni zostali do powrotu pod Wawel. Wydaje się, że to rodzina ojca jest kluczem do rozpoznania specyfiki krakowskiej tożsamości autorki Paziów króla Zygmunta. Aż trudno uwierzyć, ale tak zasłużeni dla miasta Kremerowie byli wówczas krakowianami ledwie w drugim pokoleniu. Trzej synowie krawca - Josepha Kremera, który przybył do Galicji tuż po trzecim rozbiorze, stanowią wręcz modelowy przykład fenomenu polonizacji poddanych cesarza Austro-Węgier, którzy osiedliwszy się w Krakowie, szybko się asymilowali i z ogromnym zaangażowaniem włączali w życie miasta i działania na rzecz kultury polskiej. Ojciec pisarki łączył pracę zawodową z aktywną działalnością w samorządzie lekarskim, ale też i w krakowskich instytucjach naukowych (Towarzystwie Naukowym Krakowskim, a następnie w Akademii Umiejętności). Szczególne zasługi dla miasta położyli jego dwaj bracia: Karol Kremer - architekt i pionier konserwacji zabytków oraz Józef - filozof i historyk sztuki, autor Listów z Krakowa ${ }^{16}$. Pojawienie się imion stryjów na pierwszych stronach $\mathrm{Hi}$ storii żóttej ciżemki, pozwala domyślać się, że dla Domańskiej krakowskie historie (legendy, tradycje, ale i całkiem współczesne spory o zachowanie dziedzictwa przeszłości, jak prace konserwatorskie przy Ołtarzu Mariackim czy na wzgórzu wawelskim) są nie tylko atrakcyjnymi tematami literackimi, ale historiami wręcz domowymi, których pisarka od dzieciństwa słuchała w trakcie spotkań rodzinnych ${ }^{17}$. Domańska nie mogła dobrze pamiętać stryja Karola, zmarłego w 1860 roku, ale dorastała w cieniu sławy Józefa Kremera, który prócz naukowej renomy, cieszył się opinią świetnego pisarza i wielkiego miłośnika „rzeczy” krakowskich ${ }^{18}$.

Współcześni muzealnicy miewają pretensje do Domańskiej, że wielką historię, jakiej świadkiem był Wawel, poddała swego rodzajowi „anegdotyzacji" i to, co monumentalne, zamieniła w powieściowe fabuły przykrojone do gustów mało ambitnych czytelników ${ }^{19}$. Nie wydaje się, by było taktowne

U. Bęczkowska, Karol Kremer a Józef Kremer: o obecności koncepcji estetycznych autora „Listów z Krakowa” w praktyce architektonicznej i konserwatorskiej krakowskich budowniczych połowy XIX wieku, w: Józef Kremer (1806-1875), red. J. Maj, Kraków 2007.

17 Więcej na temat związków rodziny Kremerów z Krakowem - zob. Józef Kremer (1806-1875). Studia i materiaty, red. U. Bęczkowska, R. Kasperowicz, J. Maj, Kraków 2016.

18 Zob. I. Węgrzyn, Krakowskie albumy Józefa Kremera, w: jw.

19 „Jednocześnie zauważamy, iż istnieje w odniesieniu do zamku królewskiego pewna niedobra tendencja do anegdotyzacji historii, jakiej świadkiem był Wawel. Są to historyjki rodem w najlepszym przypadku z Kraszewskiego, a przeważnie z Antoniny Domańskiej i podobnych pisarzy”. Z rozmowy przeprowadzonej z Janem 
obwinianie Domańskiej o to, co z jej dziedzictwem uczynili potomni. Nie ma natomiast wątpliwości, że Historia żółtej ciżemki i Paziowie króla Zygmunta - dwie jej najsłynniejsze powieści powinny być czytane w kontekście tych procesów kulturotwórczych, które definiują pierwsze lata epoki autonomii i prezydentury Józefa Dietla ${ }^{20}$. Innymi słowy, należy zwrócić uwagę na fakt, że utwory Domańskiej wpisują się charakterystyczny dla tamtej epoki trend swoistego przywracania krakowianom wielkich zabytków przeszłości, wręcz redefiniowania ich obecności w symbolicznym imaginarium krakowskiej wspólnoty. Jak Historia żóttej ciżemki koresponduje z dopominającym się o pamięć o polskości średniowiecznego Krakowa poematem Wincentego Pola Wit Stwosz, tak Paziowie... wpisują się w prowadzoną przez wiele lat akcję odzyskiwania dla polskości Wawelu. Wawelu, który dla ówczesnych krakowian był symbolem wielce ambiwalentnym - znakiem niegdysiejszej świetności Rzeczypospolitej, ale też znakiem zniewolenia i upokorzenia. Może więc Domańska „trywializowała” opowieść o przeszłości, zamieniając pełną patosu historię wzgórza wawelskiego w rozbrzmiewającą śmiechem „anegdotyczną” fabułę o renesansowych paziach, ale przecież to właśnie dzięki niej zacierała się pamięć o Wawelu jako sprofanowanym przez zaborców narodowym panteonie, o znajdujących się na wzgórzu austriackich koszarach i cytadeli twierdzy Kraków, wreszcie więzieniu, w którym przetrzymywany był dyktator powstania styczniowego - Marian Langiewicz ${ }^{21}$. Powieści Domańskiej okazują się więc tyleż wzorowanymi na Kraszewskim modnymi naówczas narracjami historycznymi, co i rodzajem przemyślanej interwencji we współczesność Krakowa i jego mieszkańców - interwencji mającej na celu stworzenie pozytywnej aury emocjonalnej wokół przywracanego polskiej kulturze zamku22.

Podobne napięcie między przeszłością miasta i jego teraźniejszością do-

Ostrowskim przez Michała Niezabitowskiego - zob. Muzea, muzealia, muzealnicy, red. P. Jaskanis, Kraków 2016, s. 93.

20 Więcej na ten temat - zob. J. Bieniarzówna, J.M. Małecki, Dzieje Krakowa. Kraków w latach 1796-1918, Kraków 1985, s. 239-240; I. Homola-Skąpska, Józef Dietl i jego Kraków, Kraków 1993.

21 Na temat ambiwalencji dziewiętnastowiecznej symboliki Wawelu w kontekście twórczości Wyspiańskiego - zob. E. Miodońska-Brookes, Wawel - „Akropolis”. Studium o dramacie Stanistawa Wyspiańskiego, Kraków 1980; W. Bałus, Wawel dziewiętnastowieczny: poziomy interpretacji, „Studia Waweliana” 1994, t. 3; W. Bałus, Ożywianie posągów. Glosa do „Akropolis”, w: Stanisław Wyspiański studium artysty. Materiały z sesji naukowej na Uniwersytecie Jagiellońskim 7-9 czerwca 1995, red. E. Miodońska-Brookes, Kraków 1996, s. 169-180.

22 Mowa o zainicjowanej w 1905 roku i prowadzonej do 1911 akcji wyprowadzania wojsk austriackich z zamku. 
strzegalne jest także na kartach pamiętnikarskich zapisków profesorowej. Kraków jest dla niej symbolem tradycji i wartości, ale też konkretną przestrzenią miejską - pamięć tego, co wielkie i wspaniałe, miesza się z codziennością prywatnego życia. „Stale brakuje mi miejsca, tyle ważnego dzieje się w Krakowie" - pisała Domańska. A ważne okazywało się dosłownie wszystko: strajk pomocników piekarskich, godziny otwarcia sklepów, błoto na Plantach, wylewanie nieczystości z okien domów na Podwalu, a zimą lamenty, by posypywać piaskiem ulice ${ }^{23}$. Pisarka utożsamiała się z miastem i traktowała je jako swoje:

Jak tu zmienią jeszcze choćby jedną [nazwę ulicy] - wyprowadzam się z Krakowa! Żebym JA za czyjąś głupotę ciężkim wstydem płaciła - o tego to mi już za dużo!!! Pytają się mi o ulice Psią - a ja, jak jaka Marcjanna z Kłaja, gębę ze zdumienia rozdziawiam i w dodatku idiotkę ze siebie robię, bo tłumaczę: to nie ulica, tylko Psia Górka, to teraz nieparzysta strona ulicy Wielopole... No i masz! Jeszcze czterdzieści lat temu Psia ulica zaczynała się przy Brackiej, kończyła przy Grodzkiej, a dzisiaj tu plac Wszystkich Świętych! Tu wszystko święte i sami święci w Krakowie żyją. Łajdacy, niewydarzeńcy, robigrosze etc., etc. Do Krakowa pewnie z prowincji i to tylko na chwilkę zjeżdżają... ${ }^{24}$

Co więcej, dowcipnie komentowała krakowskie komeraże i skandale, jak choćby ten wywołany przedłużającymi się pracami przy pomniku Adama Mickiewicza autorstwa Teodora Rygiera:

Trudno wyznać, czemu Kraków mianowano akurat miastem dostojeństwa i powagi, toż to miasto skandali! Komuś tam ubrdał się majestat, a tu same krotochwile, w dodatku - jak ostatnio - z Wieszczem! DWA wieszcze stoją nam w Rynku; jeden Mickiewicz i drugi Mickiewicz; jeden na piedestale, drugi ściągnięty już z niego - na bruku; jeden przyjęty, drugi odrzucony. (Mickiewicza, rzeźbionego niby, ale przecież Mickiewicza, odrzucić, ściągnąć z cokołu - na to zdobyć się może tylko Kraków!) To dopiero początek farsy, bo z tym odrzuconym nie ma co zrobić! Stanowi prywatną własność rzeźbiarza, a ten akurat nie ma czasu na zajmowanie się Wieszczem, ważniejsze interesa mu w głowie! Stoi więc sobie wyrugowany z piedestału Mickiewicz vis à vis tego wwindowanego na cokół - i różne myśli nasuwa... Mądrość oblicza jak ulał pasuje do Sienkiewicza, gdyby tak lica nieco dopasować miasto miałoby gotowy pomnik. Z profilu znowu ten odrzucony Mickiewicz Kazia Tetmajera przypomina, a to czwarty nasz wieszcz przecież, i tak z Krakowem zwią-

„Na takim właśnie odcinku ulicy Łobzowskiej całkiem obca profesorowej osoba poślizgnęła się i upadła, łamiąc nogę. »Ot! Do czego to doprowadza brak pracowitości! - grzmiała wówczas. - To JA dzień w dzień od rana do wieczora przez całą zimę sprawdzam, czy Walenty jak należy jest na posterunku i wcale nie dlatego dozoruję, żebym się grzywny bała, tylko wiem, że to jego i mój obowiązek, a tam takie niechlujstwo. Wstyd!«” (cyt. za: K. Jabłońska, dz. cyt., s. 94). „Echo Krakowa” 1980, nr 48, s. 3: W Krakowie przed 80. laty, 29 II 1900. 
zany! Włoski rzeźbione podstrzyc tylko, wąski dorzeźbić i już Kazio gotowy, czeka sobie na odsłonięcie. Co to jednak znaczy twór GENIALNEGo rzeźbiarza - tyle rozległych możliwości stwarza!...25

Do zabawniejszych zapisków Domańskiej należą te poświęcone krakowskim cyklistom:

Plaga machin zwanych rowerami rozplenia się w naszym mieście coraz bardziej. Rower staje się w Krakowie czymś, co świadczy o pozycji, nadążaniu za postępem i modą. Aż strach pomyśleć, jakie stanie się tu życie, kiedy każdy postępowy młody człowiek, dobrze sytuowany, będzie pędził na tym wehikule. Toż to o wypadek bardzo łatwo! Powinno się zabronić jeżdżenia po mieście; w ogóle prezydent powinien wzbronić wwozu tych machin do miasta. ${ }^{26}$

W 1904 roku z jeszcze większym przejęciem notowała:

Mało trupem nie padłam dzisiaj [w księgarni] u Gebethnera! Wybieram nowości i co widzę? - Powieść Prusa Ze wspomnień CYKLISTY... BEZWSTYdNIK jeden publicznie wyznaje, że jeździ na tej potwornej machinie. Fuj! Wielki pisarz na - rowerze! Skandal, popsucie obyczajów!!! Proszę dobrze zapamiętać sobie - od dziś pan Prus dla mnie nie istnieje zupełnie! ${ }^{27}$

W tym samym roku do listy potępianych nowinek technicznych pisarka dodała jeszcze automobile:

A mówiłam, mówiłam, tylko MNIE nikt nie słucha, no to i w Krakowie już mamy automobil - machinę poruszającą się za pomocą motoru; osiągnięcie najnowszej cywilizacji, jak to uczenie mawia się obecnie o ludzkiej głupocie. Wszyscy zachwyceni! Taki Mycielski, taki Tomkowicz, a Kossak, Wyczółkowski - jak to-to w Rynku zobaczyli, zaraz poczuli się w samym środku PARYżA!!! Jak to łatwo zbaranieć. Wystarczy odrobinę smrodu w nos wciągnąć, posłuchać: Tur! Tur! Tur! Pfuu! Pfuu! Pfuu! Popatrzeć na ów automobil i wariactwo gotowe! Stoisz na krakowskim Rynku, patrzysz na Sukiennice i Paryż widzisz!!! CıEKAWE!!!

No, MNIE nikt nie otumani! Możem staroświecka, zacofana nawet, ale niech nikt

25 Korespondencja Domańskiej z maja 1898 roku, cyt. za: J. Adamczewski, Ech, mój Krakowie, Kraków 1980, s. 256-257. Jan Adamczewski przekazał jeszcze jedną, wartą przytoczenia anegdotę: „[...] w roku 1904 zanotowała pani Domańska opowiastkę, o tym jak to »Czas« zamierzał postawić w Rynku pomnik Dżimusiowi [charcik Karola Estreichera] za to, że dzwoneczkiem zawieszonym na obroży wyprzedza zawsze nadejście Estreichera i wtedy w redakcji rozlega się alarm: chowaj gazety, kto w Boga wierzy - bo Estreicher rozgląda się bacznie i co mu tylko ciekawego w oczy wpadnie, zabiera zaraz i do Biblioteki zanosi" (J. Adamczewski, Krakowskie rody, Kraków 1994, s. 43).

26 „Echo Krakowa” 1979, nr 179, s. 3: W Krakowie przed 80. laty, 13 III 1899.

27 „Echo Krakowa” 1979, nr 214, s. 3: W Krakowie przed 75. laty, 24 IX 1904. 
mi nawet nie próbuje wmawiać, że ten tam automobil to cywilizacja. To zDzICZENIE! Lekceważenie dobrych obyczajów! Czytam sobie dzisiaj „Czas” [...] a tu mi ów automobil charczy pod domem. Jedzie taki, bo ma ochotę i ludzi hałasem nęka. EGoISTA! [...] i po co się to fabrykuje, żeby ludziom zakłócać poobiedni odpoczynek. ${ }^{28}$

Gwałtownie protestując przeciwko tym widomym znakom nowoczesności, pozostawała jednak Domańska wyjątkowo trzeźwą obserwatorką działań ruchu krakowskich starożytników. Szczególnie musieli dopiec jej dwaj przyjaciele męża i stali bywalcy salonu profesorstwa - Stanisław Tomkowicz i Klemens Bąkowski, którzy gorąco protestowali przeciwko wszelkim modernizacjom, gdy rozważano konieczność przeprowadzenia remontu w kamienicy Domańskich przy ulicy Szczepańskiej 8. Uczeni mężowie debatowali nad wartością śladów przeszłości, a zirytowana profesorowa komentowała:

Chcesz majątek utopić - dom remontuj w KRAKOWIE! A zdradź się z tym takiemu Tomkowiczowi czy Bąkowskiemu, zaraz się dowiesz, że schody do piwnicy, które przeklinasz za każdym schodzeniem do tego lochu - to cenny ślad kamieniarskiego dzieła dawnych rzemieślników krakowskich. Wyślizganych, obrzydliwych ropuch (klamek), których, chcesz nie chcesz, dotknąć musisz kilkadziesiąt razy dziennie, bo jak inaczej sobie drzwi otworzysz - wymienić nie należy, bo to także cenne, stare arcydzieła! No, służą wiernie, to racja, ale czy na te „zabytki” mam być skazana dożywotnio?! Może powinnam jeszcze powrócić do łuczyw albo kurny komin wprowadzić - co?! Ten komin to nie byłby taki zły. W zasięgu jego dymu sadzałabym sobie to pana Tomkowicza, to Bąkowskiego albo i obu pospołu, podświetlałabym ich sobie łuczywkiem i z ogromną satysfakcją serwowałabym im na liściach łopianu, albo i wprost do łapek, zadymione, przypalone na węglach placki z ledwie roztartej na żarnach pszenicy. Ale by mieli BARANIE miny! A ja ukontentowana słodziutko tłumaczyłabym: - To taki przysmak naszych przodków, a jak już siedzimy w gmaszydle pełnym śladów przeszłości, ogłaszam całkowity powrót w pradawne czasy... ${ }^{29}$

Najbardziej krakowski spośród tych obrazków wydaje się jednak poniższy kilkuzdaniowy fragment. Spojrzenie Domańskiej, niczym fotograficzna migawka, rejestruje tu krakowską codzienność - zatrzymuje ulotną chwilę miejskiego rozgardiaszu, chwilę pozornie bez znaczenia, ale tak pełną poezji:

Tutaj wszyscy grzebią się w przeszłości i dumają: Jak to było? Co to było? Gdzie to było? A czyż dzisiejszy dzień nie jest piękny w Krakowie? Tu Włodzio Tetmajer wymienia ukłony. Tam Lucek [Rydel] gna, jak zwykle spieszy się bardzo i czasu znowu mu brakuje, po północ przegadał i z pewnością zaspał. Godnie drobi kroczki Papieżyca [hrabina Potocka]. Godnie kroczy Największe Bóstwo Olimpu - Kazimierz Tetmajer we własnej osobie! Za nim adoratorzy, adoratorki... A na Rynku, jakby nic, targ się toczy. Przy Sukiennicach baby nabiałem handlują. Pachołki pie-

29 „Echo Krakowa” 1980, nr 205, s. 5: W Krakowie przed 80. laty, 24 IX 1900. 
karskie chleby i kołacze sprzedają, przy wieży ratuszowej drób wrzask podnosi i hałas czyni, dalej leżą MILczĄco mięso i kiełbasy. A za nimi misy i garnki gliniane targują... Czyż to aż przeszłości trzeba do wywoływania krasy miasta? ${ }^{30}$

\section{„Mego zdania to nie zmienia”. Antonina Domańska - pisarka}

Nazwisko Antoniny Domańskiej z rzadka jedynie pojawia się w pracach poświęconych polskim pisarkom XIX stulecia, co zważywszy na ogromną popularność jej powieści historycznych może nieco dziwić31. Zupełnie natomiast nie dziwi fakt, że nikomu nie przyszło na myśl, by włączyć Domańską w szeroki nurt postaw emancypacyjnych tamtej epoki ${ }^{32}$. W niewielkim stopniu „zawinił” tu Wyspiański, który (przypomnijmy) kreśląc postać Radczyni, uczynił z niej figurę mieszczańskiego konserwatyzmu. Profesorowa sama dbała, by postrzegano ją jako jedną z tych kobiet, które gwarantowały ciągłość paternalistycznego ładu mieszczańskiego świata. W życiu codziennym i na kartach swych pamiętników Domańska z wyraźną satysfakcją przybierała pozy nobliwej matrony, matki i pani domu:

Umęczonam do ostatnich granic, ale wszystko, wszystko w domu ruszyłam, nie przepuściłam żadnej rzeczy, żadnemu drobiazgowi. Resztę sił tracę na dozorowanie upinania kotar, zasłon i firanek. Jeszcze gotowanie, jeszcze pieczenie mnie czeka... Pan domu niezbyt kontenty... to amoniak nosek mu drażni, to zaprawa śmierdzi, śledzie niemile wonieją, choć później będzie je pałaszował!... Dzisiaj nawet zagadnął, kiedy To wreszcie się skończy? A ja najsłodziej - Co, kochanie, co? - No, ten cały bałagan... Czyż dla siebie skazuję się na takie tortury, na mękę graniczącą z utratą sił, zdrowia - dla domu przecież. Huknęłam więc: Jaki znowu bałagan?! To tylko przedświąteczne, generalne porządki - misterium i TRADYCJA!33

„Echo Krakowa” 1980, nr 125, s. 5: W Krakowie przed 80. laty, 4 VI 1900.

31 Wyjątki to poświęcony Domańskiej biogram w kompendium Współcześni polscy pisarze i badacze literatury: słownik biobibliograficzny, oprac. zespół pod red. J. Czachowskiej i A. Szałagan (Warszawa 1994, t. 2, s. 188-190) oraz szkic w Obrazie literatury polskiej. Zob. H. Skrobiszewska, Antonina Domańska (1853-1917), w: Obraz literatury polskiej XIX i XX w., red. K. Wyka, H. Markiewicz, I. Wyczańska, seria 5: Literatura okresu Młodej Polski, red. K. Wyka, A. Hutnikiewicz i M. Puchalska, t. 3, Kraków 1973. Hasła poświęconego Domańskiej nie ma w Nowym Korbucie ani w przewodniku Dawni pisarze polscy. Od początków piśmiennictwa do Młodej Polski. Nie uwzględniły postaci Antoniny Domańskiej także autorki tomu Pisarki polskie - zob. G. Borkowska, M. Czermińska, U. Phillips, Pisarki polskie. Od średniowiecza do wspótczesności. Przewodnik, Gdańsk 2000. Nie ma wzmianki o Domańskiej w żadnym z pięciu tomów opracowania Krakowski Szlak Kobiet. Przewodniczka po Krakowie emancypantek, red. E. Furgał, Kraków 2010, 2011, 2013. 
W innym miejscu pisała:

Strajkują piekarze, strajkują cholewkarze, coś knują stróże i zawsze ktoś bierze to pod uwagę. Tylko ze mną nikt się nie liczy. A czy to nie praca na co dzień od rana do nocy dysponować, popędzać, nauczać, pilnować służbę? Dosyć tego! - powiedziałam sobie. Ogłaszam strajk! Mówię więc memu panu: Jadę do Zakopanego, porządź trochę, pogospodaruj sobie domem! Obiady dysponuje się na cały tydzień, przepierki co czwartek, w piątki prasowanie, sobota - gruntowne sprzątanie... Zakopane świetnie ci zrobi! - sięga po kluczyk do swej prywatnej szkatuły! Boleśnie tym raził mnie w samo serce!... Jak o moją rękę się starał, godzinami wystawał, żeby bodaj mój cień w oknie ujrzeć, a teraz pod oknami nie wystaje, kwiatów nie przynosi i jeszcze ochoczo przystaje na mój wyjazd. O nie! Za próg się nie ruszę. Będzie wszystko po staremu, bo prawo do strajku mają wszyscy, tylko nie - ja!34

Trudno nie dostrzec ironicznego retuszu, jaki Domańska nanosiła na swój wystudiowany autoportret. Profesorowa z dezynwolturą „bawi się” pełnioną przez siebie rolą, ale odgrywając zagonioną kurę domową, równocześnie dystansuje się i wobec „swego pana” małżonka, i własnych prób osiągnięcia wyśrubowanego ideału kobiecości swej epoki i swej sfery. Zdradza ją ironiczny dystans i ujawniane w wielu fragmentach tych zapisków uzależnienie od literatury, co żartobliwie wypominał jej nawet mąż:

Chcesz mieć święty spokój i przynajmniej w okresie świątecznym choć trochę odpocząć? - kup swej Szanownej Magnifice Średniowieczną historię naturalną Józia Rostafińskiego! Wypróbowałem, to najbardziej skuteczny środek na opędzenie się od codziennej troskliwości małżeńskiej, od tego pilnowania: czy właściwa chusteczka do właściwej kieszeni włożona, czy mój kaszel to tylko przelotna chrypka, czy też symptomy, nie daj Panie Boże!, influenzy. Moja żona, jak się do tej historii Józia dorwała, o bożym świecie zapomniała. Nawet odeszła ją chętka na zapowiedziane - pogłębienie najgeneralniejszych porządków przedświątecznych, takich, które - jak to dobrze wiesz - dom po prostu wywracają do góry nogami, mało! unicestwiają na dni kilka ludzkie bytowanie... Miałbym dłuższy spokój, gdyby nie te święta, wszak małżonka ciasto piec SAMA MUSI!!! 35

Wystarczy jednak sięgnąć do katalogów warszawskiego wydawnictwa Michała Arcta i poznańskiej Księgarni św. Wojciecha, gdzie Domańska publikowała, by dostrzec, jak bardzo ta opowieść o krakowskiej matronie, rozdartej między obowiązkami domowymi, smażeniem pączków i przedświątecznymi porządkami a przyjemnością lektury, nie pasuje do rzeczywistości.

W kontekście twórczości Domańskiej mnożą się pytania, na które nie znam odpowiedzi: czy jako autorka wspomagała domowy budżet i pisała

34 „Echo Krakowa” 1980, nr 50, s. 5: W Krakowie przed 80. laty, 3 III 1900.

35 Korespondencja Stanistawa Domańskiego, „Echo Krakowa” 1980, nr 272, s. 3: W Krakowie przed 80. laty, 17 XII 1900. 
(lub tłumaczyła) w celach zarobkowych? Pozycji w jej bibliografii jest zbyt wiele, by traktować je wyłącznie jako rodzaj rozrywki znudzonej czy też jedynie bawiącej się literaturą damy. Czy jako autorka Domańska realizowała zlecenia wydawców, czy sama proponowała tematy i tytuły? Czy formy pamiętnikarskie wykorzystane w Moich dzieciach, w serii o lalce Stokrotce Miluni i w Historii jednej papugi były literacką inspiracją jej własnych pamiętnikarskich zapisków czy wręcz przeciwnie, to potrzeba ekspresji indywidualnego doświadczenia uczyniła z Domańskiej autorkę powieści wykorzystujących formy pamiętnikarskie? Wreszcie, jak interpretować sprzeczność między głośno deklarowanym przez profesorową oporem wobec kształcenia kobiet a obecną w jej utworach tendencją dydaktyczną i świadomością znaczenia roli kobiety $\mathrm{w}$ rodzinie i społeczeństwie?

Antonina Domańska nie była emancypantką. Pani profesorowa zapewne poczułaby się głęboko urażona samym posądzeniem, że mogłaby nią być. Ale czy nie jest rodzajem gestu emancypacyjnego decyzja kobiety, takiej jak ona, by publikować swe utwory i jeszcze na nich zarabiać? By wystawiać na widok publiczny intymność codziennych zabaw z dziećmi, wycieczek i domowych rozrywek? By jawnie (wszak dziecięcy bohaterowie nosili imiona jej dzieci) odsłaniać autobiograficzny kontekst swych utworów? Nawet jeśli przyjąć, że Domańska wykorzystywała literackie schematy ukształtowane przez biedermeierowskie pisarki niemieckiego kręgu językowego, to i tak jej utwory, wyróżniając się oryginalnością i szczególnym liryzmem, stanowią ciekawy przykład wpływu ruchów emancypacyjnych na konserwatywne środowiska mieszczańskie. W jakiejś mierze przykład Domańskiej podpowiada, że poszukując pionierek nowoczesnej kobiecości, nadmiernie bagatelizujemy zjawiska zachodzące w środowiskach deklarującej tradycjonalizm inteligencji końca XIX wieku. Szeroko pojmowany polski ruch emancypacyjny nie był kształtowany wyłącznie przez sufrażystki i socjalistki, ale także, przynajmniej w jakiejś mierze, i przez przedstawicielki konserwatywnego mieszczaństwa - działaczki filantropijne i podobne Domańskiej literatki, które dyskretnie rozsznurowywały gorset mieszczańskiej poprawności.

Bibliografia prac Antoniny Domańskiej udowadnia przy okazji, że urocza opowieść o roli Lucjana Rydla jako inspiratora literackich zatrudnień ciotki jest o tyle prawdziwa, o ile odnosić ją do zdominowanej przez tematy historyczne twórczości po 1910 roku. Zapomniana już dziś wcześniejsza twórczość pisarki, choć zapewne mniej oryginalna i słabsza artystycznie, stanowić może ciekawy przyczynek do historii polskiego piśmiennictwa dla dzieci. Znamienne przy tym, że to dopiero programy szkolne II Rzeczypospolitej 
tak jednoznacznie zdefiniowały hierarchię utworów autorki Paziów króla Zygmunta. Dla swych współczesnych, jak poświadcza nekrolog w „Czasie”, pozostawała raczej pisarką domowej intymności, „poetką lalek i dzieci”:

Ale choćby historia literatury zapomniała zupełnie o Pamiętniku Stokrotki i Moich dzieciach, to nasze dzieci opowiadać będą jeszcze swoim dzieciom i wnukom, jakie to śliczne książki czytywały za młodu. A taka sława żywa nie mniej warta od papierowej: ukochanie przez tysiące dzieci i matek nie mniej od uznania kilku „fachowców".36

"Mego zdania to nie zmienia” - dwa razy powtarza Radczyni w rozmowie z Panem Młodym pod koniec pierwszego aktu Wesela. Słowa te padają nieprzypadkowo, są rodzajem charakterystyki tradycjonalizmu mieszczaństwa końca XIX wieku, ale w kontekście drogi życiowej Antoniny Domańskiej nabierają też innego, głębszego sensu. Pisanie bowiem, jak się okazuje, było dla Domańskiej nie tyle rozrywką, co ważnym gestem tożsamościowym, znakiem przynależności do świata wartości reprezentowanych przez krakowską konserwatywną inteligencję, a równocześnie sposobem artykułowania jej własnej indywidualności. Jak w powieściach historycznych przerzucała mosty między swą współczesnością a czasem minionym, tak w utworach o dzieciach i dla dzieci konstruowała figury wiecznej kobiecości: Mamusi, Babuni, Cioci - postaci, które opowiadając świat, gwarantowały jego stabilność i ciągłość. Może nawet, trochę jak pani Dulska z przejmującej interpretacji Dymitra Fiłosofowa ${ }^{37}$, była Domańska w jakiejś mierze postacią tragiczną, która w obliczu nadchodzącej katastrofy pierwszej wojny światowej i nieuchronnego końca mieszczańskiego świata nie chciała poddać się losowi i opowiadając swe historyjki o dzieciach, lalkach i papugach, podtrzymywała iluzję jego trwania:

Pół wieku minęło, babunia dawno już w niebie, a jej bajki spłoszone prawdą życia, pouciekały prawie wszystkie z mej pamięci. Ledwie gdzieś głęboko w sercu, na samym dnie dziecinnych wspomnień zostały drobne urywki i blade jak mgła postaci zaklętych rycerzy i dobroczynnych wróżek.

Staram się obudzić do życia te cienie, zebrać porozrzucane drobne okruchy...

a.s. [A. Świderska?], Poetka lalek i dzieci. Śp. Antonina Domańska, „Czas” 1917, nr 53, s. 2. W niektórych opracowaniach kryptonim ten jest przypisywany Tadeuszowi Since, jednak recenzja napisana została z pewnością przez kobietę. Autorką tej recenzji jest prawdopodobnie ALINA ŚWIDERSKA (1875-1963) - powieściopisarka i tłumaczka (dziękuję Magdalenie Rudkowskiej za ten trop). D. Fiłosofow, To, co wiecznie mieszczańskie i wiecznie żandarmskie $w$ sztukach pani Zapolskiej, w: tegoż, Pisma wybrane, t. 2: Rosjanin w Polsce (1920-1936), wybór i oprac. P. Mitzner, Warszawa 2015, s. 114. 
Dziś, jak owa dobra babunia, przynoszę wam na gwiazdkę snopek baśni czarodziejskich i pragnę gorąco, by się wam bardzo podobały. ${ }^{38}$

\section{„Ten” Wyspiański}

Antypatia Antoniny Domańskiej względem Stanisława Wyspiańskiego była tematem wielu krakowskich anegdot. Profesorowa spotykała się z artystą w salonie Elizy Pareńskiej i ponoć zupełnie nie mogła pojąć entuzjazmu, jaki wzbudzała jego twórczość. Krystynie Jabłońskiej udało się uchwycić zabawny dwugłos.

Najpierw Domańska:

Spotykam dzisiaj w Rynku profesorową Pareńską i mówię jej tak: Może i nie znam się na malarstwie, może mam wprost zły gust, ale jak można do Sukiennic, pod jeden dach z Matejką, Siemiradzkim, Wyczółkowskim, że tych tylko wymienię pchać niewydarzone malowidła tego Wyspiańskiego. A wiem, proszę mi nie zaprzeczać, bo wiem, że to na pewno pani robota. Bardzo NIEŁADNA robota, bo ten Wyspiański, żeby na głowie stawał, nigdy nie namaluje ani Grunwaldu, ani Czwórki, ani wreszcie kwiatów Wyczółkowskiego. Coś tam pochlapie, pomaże, rozmaże i każe wierzyć, że to akurat kaczeńce. Ja już go znam! A ona mi na to: - Droga pani, nikt do malowania na głowie nie staje, nawet Styka i to maluje na klęczkach, ale jedynie Chrystusa, wszyscy malują stojąc - to raz. Po wtóre gdyby TEN Wyspiański, jak to podkreśliła, TEN WYSPIAŃSKI, odmalował Grunwald, Czwórkę czy Kaczeńce, wobec twórców tych arcydzieł popełniłby przynajmniej grubą nieprzyzwoitość. Wreszcie Wyspiański GENIALNY artysta tworzy według własnych wizji... W paryskim nowiutkim kapelusiku, w nowiutkiej paryskiej tualecie, subtelnie woniejąca tuberozą rozdziela uśmiechy na lewo, na prawo i słodziutko wszystkim wmawia GENIUSz tego pacykarza. O nie, droga pani, mnie Wyspiańskiego NIE wmówisz! ${ }^{39}$

\section{Następnie replika Pareńskiej:}

Od Domańskiej wprost średniowieczem wonieje! Rysowanych przez Wyspiańskiego, do naszych kościołów, świętych uważa za zniewagę, za profanację już nie kościoła jako budowli, tylko - religii. Ma ich za skandaliczną herezję etc. Jej sprawa! Uczepiła się przecież mnie i piekłem mi grozi, że tak foruję Stasia, mniejsza z tym. ${ }^{40}$

Sprawa stanęła na ostrzu noża, gdy Domańska zagroziła, że jeśli Pareńska nie poniecha zażyłej znajomości z Wyspiańskim, to ona - profesorowa Domańska - wymówi jej swój salon.

38 A. Domańska, Przy kominku. Opowieści fantastyczne dla mtodzieży, Kraków 1911. Utwór dedykowany Lutkowi i Helence Rydlom.

39 K. Jabłońska, dz. cyt, s. 57. Ten sam fragment: „Echo Krakowa” 1980, nr 117, s. 5: W Krakowie przed 80. laty, 26 V 1900.

40 Cyt. za: K. Jabłońska, dz. cyt., s. 58. 
Takie właśnie drobne wojny podjazdowe obie damy ku uciesze całego Krakowa, a później badaczy twórczości autora Wesela, prowadziły o Wyspiańskiego. Oczywiście przyszłość rację przyzna Pareńskiej. Dziś już nikt nie poddaje w wątpliwość wartości dzieł „tego Wyspiańskiego”. Zamiast jednak deliberować nad brakiem gustu Domańskiej, warto zwrócić uwagę, że jej opinie wyrażały poglądy zdecydowanej większości ówczesnych krakowian nawet nie tyle przeciwnych nowej sztuce, co nią zdziwionych czy wręcz zaszokowanych. Potępiając styl życia Wyspiańskiego, krytykując jego ekstrawagancje i zupełnie, ale to zupełnie nie rozumiejąc jego sztuki, Domańska nie potrafiła nie śledzić jego poczynań. W jej zapiskach daje się wyczuć rodzaj wręcz hipnotycznej fascynacji postacią artysty:

Ożenił się [18 X] ten Wyspiański, czy nie?! Różnie mówią. Jedni mi świadczą, że tak i to bardzo podle, dużo niżej od swej sfery. Inni zaprzeczają - to jest niemożliwe! Taki esteta z tak prostą dziewczyną - nie! nie! Obrączki nie nosi, żony nie prezentuje, więc jak to jest! Nic mi właściwie do tego, ani mnie to ziębi, ani mnie to grzeje, ale jak się już ktoś żeni z tak zwanego towarzystwa, to niech żeni się, jak zwyczaj tego wymaga. Włodzio Tetmajer, jak się żenił przed laty z Bronowicami, to w święto, wprost na sumę do kościoła NPM wozem z paradą zajechał, otwarcie - jak Bóg przykazał. A Wyspiański w pustym, podobno nawet zamkniętym na ten czas kościele, stanął z oblubienicą przed ołtarzem. Więc coś tu jest nie tak, coś się za tym kryje, ale co? I czy on się ożenił, czy tylko tak plotą? Dużo dałabym, żeby prawdy się dowiedzieć! 41

Kilka miesięcy później Domańska znów wróciła do tematu w prywatnym liście:

Jeśli sam jeszcze nie wiesz, to podpytaj jakoś zręcznie p. St. Estreichera, co też takiego pisze Wyspiański? Takie słuchy dochodzą do mnie, że coś na mój temat. Co to też może być i z jakiej racji ja w roli muzy geniusza? Mój drogi, dowiedz się koniecznie, proszę! 42

Na zakończenie raz jeszcze chciałabym upomnieć się o sprawiedliwość dla Antoniny Domańskiej. Badacze twórczości Wyspiańskiego z lubością przywołują jej złośliwe impertynencje, którymi w czasie przygotowań do pogrzebu artysty podsumowywała swoje z nim stosunki. Często cytowany jest poniższy fragment:

Nieźle ten śp. Wyspiański mącił tu za życia, nieźle i stale! Pomijam osobiste bóle, w niepamięć puszczam mu swoje poniżenie, ale on mąci stale, wszędzie, wszystkim i każdemu. No i teraz daje z trumny ostatni popis swoich mącicielskich talentów. Przemawia przeze mnie gorycz, ale com się przez niego nacierpiała, nikt nie 
zgadnie. Nawet Bałucki, nawet taka Zapolska - nie zahaczyli nigdy mnie słówkiem, a TEN żółtodziób: RADCZYNi!!!! Niech mu ziemia lekką będzie! Nie sympatyzowałam z osobistością, ale wieczny odpoczynek racz mu dać Panie! ${ }^{43}$

W obliczu śmierci ta szarża pani profesorowej wydaje się wyjątkowo małostkowa. Domańska, choć tak się przed tym wzbraniała, sama ujawniałaby, jak bardzo jednak była Radczynią - właśnie taką, jaką zobaczył ją Wyspiański.

Problem jednak w tym, że wyrwany z kontekstu fragment znaczy zupełnie inaczej, niż gdy staje się częścią większej całości. Otóż ta ostania wymierzona w Wyspiańskiego diatryba profesorowej okazuje się częścią większej kampanii, która w rzeczywistości miała na celu obronę dobrego imienia artysty. Domańska starła się z prezydentem miasta - Juliuszem Leo, który (przynajmniej tak twierdziła profesorowa) próbował zbić kapitał polityczny w czasie pogrzebu Wyspiańskiego. Rzecz poszła o projekt prezydenta, by uroczystość została sfilmowana.

Patrząc z dzisiejszej perspektywy, pewnie trochę szkoda, że ostatnia droga artysty nie zachowała się do naszych czasów, utrwalona na taśmie filmowej ${ }^{44}$. Jednak Domańska, protestując przeciwko „żywym obrazom”, miała swoje racje. Nie tylko pytała, czy sam Wyspiański by sobie tego życzył, ale przede wszystkim chciała bronić jego godności - godności człowieka, którego wyniszczone, zdegradowane chorobą ciało zagrażało, jej zdaniem, pamięci artysty i powadze uroczystości.

W swym macierzystym kontekście zacytowany wcześniej fragment wybrzmiewa zupełnie inaczej:

Zawsze mówiłam: komuś się tam ubzdrało: Kraków miastem dostojeństwa, powagi - a toć miasto SKANDALI! I to jakich!!! Tylko MNIE nikt nie słucha, ot, co! A swoją drogą, jak to natura z człowieka nawet po jego śmierci wychodzi. Nieźle ten śp. Wyspiański mącił tu za życia, nieźle i stale! Pomijam osobiste bóle, w niepamięć puszczam mu swoje poniżenie, ale on mąci stale, wszędzie, wszystkim i każdemu. No i teraz daje z trumny ostatni popis swoich mącicielskich talentów. Przemawia przeze mnie gorycz, ale com się przez niego nacierpiała - nikt nie zgadnie. Nawet Bałucki, nawet taka Zapolska - nie zahaczyli nigdy mnie słówkiem, a TEN żółtodziób: RADCZYNi!!!!

Niech mu ziemia lekką będzie! Nie sympatyzowałam z osobistością, ale wieczny odpoczynek racz mu dać Panie! Tylko zanim w spokoju spocznie - dostąpi jeszcze profanacji żywymi fotografiami. I tu żal mi go - jako zmarłego, któremu już tylko cześć, hołd i szacunek się należy, a którego pan prezydent Miasta Krakowa - prof.

44 Zob. A. Urbańczyk, Kinematograf na pogrzebie Wyspiańskiego, w: A. Urbańczyk, Z. Wyszyński, Wyspiański w krainie filmu, Kraków 1987, s. 33-36. 
dr Juliusz Leo - na despekt, szwank i niespokój pośmiertny tymi żywymi fotografiami naraża. Bądźmy ludźmi! Jak tak sobie pomyślę, że to ja już w trumnie leżę w tej sukni perełkami haftowanej, z żywym kwiatem tuberozy u skroni i tu ktoś mi robi fotografię - żYWĄ fotografię - nie! nie! myśleć nie sposób, że ktoś w takiej chwili mnie podgląda. No, jak ja się będę czuła. Na pewno fatalnie! A jak on, ten Wyspiański będzie się czuł, pokiereszowany w dodatku tą swoją chorobą wstrętną?!

Uczcijmy majestat śmierci! Czy pan prezydent jednak wie, co to majestat śmierci?! Nie!!! Fotografii żywych z pogrzebu Wyspiańskiego się mu zachciewa. Po co to komu? Na co? Pamiątka! Dokument! To niby on taki postępowy. Rudi [Rudolf Starzewski] z Włodziem poślą mu sekundantów. Już to by uczynili, tylko najpierw pogrzeb Wyspiańskiego uczcić chcą, no i trzeba się przekonać, czy pan prezydent może dać honorową satysfakcję. Czy taki Leo ma ku temu odpowiednie parantele?

Oburzonam do żywego. Nawet nie ma tu z kim akurat mówić w tej sprawie. Napisałam drętwą „mowę” do J.E. Tarnowskiego, ale czy go ruszy? Namiestnikowa z panem prezydentem trzyma: - W Wiedniu żywe fotografie oglądała. Dokument dla potomnych! Ale co mnie potomni obchodzą! Będą to ciekawi pogrzebu Wyspiańskiego z żywych fotografii? A kto to wiedzieć może? A jemu despekt i sromota. Co za czasy! Żeby śmierci, pogrzebu nie uszanować! Najwięcej mogłaby Profesorowa. Tej nie ma. Wyjechała. Nie wróci. Córeczka umierająca. Mniejsza o to, ale z nią pan prezydent się liczy! Dojdzie do sromoty. Od Pijarów po Paulinów będzie biegał pajac i dla pana prezydenta i jego potomnych będzie żywe fotografie robił. Za sto lat cóż za utopia - każdy chętny będzie mógł naocznie przekonać się, w jakim to majestacie za trumną Stanisława Wyspiańskiego pan prezydent Leo kroczył, jaką to miał minę dostojną, a jaki krok dygnitarski. A wcale bym się nie dziwiła, gdyby tak nagle gdzieś w Rynku lub na Stradomiu Wyspiański grzmotnął i pana prezydenta, i tego fotografa błazna w gęby. Ale czym - jak już nie miał pięści. ${ }^{45}$

Ten fragment zapisków Domańskiej odnalazłam w Bibliotece PAU wśród dokumentów należących do spuścizny prof. Jerzego Gota. Brak jednak adnotacji o źródle jego pochodzenia - przepisany na maszynie fragment może być odpisem z oryginału, ale może też być notatką z książki Andrzeja Urbańczyka i Zbigniewa Wyszyńskiego Wyspiański w krainie filmu. Urbańczyk wskazywał źródło materiałów, do których dotarł „dzięki życzliwej uprzejmości p. Krystyny Jabłońskiej, autorki prac o obyczajowości krakowskiej w końcu XIX w." ${ }^{46}$. I tu zamyka się koło moich poszukiwań. Znowu jedynym

PAU Kraków, sygn.. 13308, k. 42-43. Spuścizna Jerzego Gota. Prace naukowe J. Gota z dziedziny teatrologii, maszynopis. Powyższe zapiski uzupełnia brudnopis listu Domańskiej do Stanisława Tarnowskiego, w którym profesorowa prosi o „łaskawe użycie [...] swych nieograniczonych wpływów i udaremnienie p. prezydentowi urządzenia tej perfidnej szopki. Tego przecież wymaga i nasza tradycja i szacunek dla zmarłego". Na potrzeby niniejszego tekstu rozwinięte zostały skróty zamieszczone w notatkach Jerzego Gota.

A. Urbańczyk, dz. cyt. 
adresem, pod którym można szukać pamiętnikarskich zapisków Domańskiej, okazuje się autorka Ostygłych emocji...

20 maja 2017 roku na deskach Teatru Słowackiego Agnieszka Glińska swym przedstawieniem $Z$ biegiem lat, z biegiem dni. Gdzie jest Pepi? powróciła do legendarnego dzieła Andrzeja Wajdy z 1978 roku. Mieszczańska epopeja utkana przez autorkę scenariusza, Joannę Olczak-Ronikier, z fragmentów dramatów Bałuckiego, Zapolskiej i Kisielewskiego tym razem wybrzmiała w melancholijnej tonacji poszukiwania śladów pamięci po żydowskich mieszkańcach Krakowa przełomu wieków. Nie potrafię oprzeć się analogii poszukiwań podjętych przez reżyserkę wobec detektywistycznej szarady, jaką stanowią dzieje pamiętnikarskich zapisków Antoniny Domańskiej i przesłonięta legendą Wesela historia ich autorki.

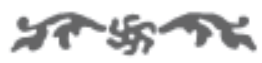

I wona Węgrzyn (Jagiellonian University in Kraków)

e-mail: iwona.wegrzyn@uj.edu.pl, ORCID:0000-0001-6591-9446

ANTONINA DOMAŃSKA - SKETCH FOR A PORTRAIT

A B S T R A C T

This essay is an attempt to remind Antonina Domański's (1853-1917) character and works. Reconstructon of the biography of the writer was based on diary materials, private letters and statements of witnesses of the epoch. Domańska is shown as a personality wrongly entangled in the framework set by the reception of Stanisław Wyspiański's masterpiece "The Wedding”. Her story proves to be an interesting contributor to the history of Cracow at the end of the 19th century.

K E Y W O R D S

Antonina Domańska, novels for children, conservative tradition, bourgeoisie, Cracow, Stanisław Wyspiański 